\title{
高温非平衡プラズマによる $\mathrm{SiO}_{2}$ 膜の作製*
}

\author{
高城 信二** ·関口 敦** .三戸 英夫**
}

（昭和63年 1 月 4 日 受理)

\begin{abstract}
Depostion of $\mathrm{SiO}_{2}$ Thin Films by High Temperatur Non Equilibrium Plasma
Shinzi TAKAGI**, Atsushi SEKIGUCHI** and Hideo MITO**
\end{abstract}

(ANELVA Corporation, 5-8-1 Yotsuya, Fuchu-shi, Tokyo)

(Received January 4, 1988)

\section{1.はじめに}

半導体製造工程においてグロ一放電プラズマによる低 温プロセスが多く用いられている。これに対し我々は局 所的に輝度が高く, 気体の温度が通常のグロ一放電プラ ズマの場合と比較して高くなっている状態のプラズマに 着目した。このよらなプラズマをここでは高温非平衡プ ラズマと呼ぶことにする. 我々はこの高温非平衡プラズ マから多量の活性種と高輝度の真空紫外光が得られてい ることを報告した ${ }^{1,2)}$. 今回この活性種と高輝度の真空 紫外光を用いて $\mathrm{SiO}_{2}$ 膜の作製を試み, その膜の諸特性 および成膜メカニズムについて検討したので報告する.

\section{2. 実験装置および方法}

Fig. 1 に本実験で用いる装置の構成図を示す。プラズ マは石英ガラスの二重管でできた放電管の内部に高周波 誘導結合により発生させる。高周波電源としては13.56 $\mathrm{MHz}$ の $5 \mathrm{~kW}$ 他励式電源を用いており, 放電管に電力 を供給している。また放電管を水冷することによりプラ ズマからの熱による放電管の損傷を防止している。また 基板はヒータにより加熱され, PID 制御により温度を 一定に保つょうになっている.今回の成膜では亜酸化窒 素 $\left(\mathrm{N}_{2} \mathrm{O}\right)$ 抢よびシラン $\left(\mathrm{SiH}_{4}\right)$ によってシリコン酸化 膜 $\left(\mathrm{SiO}_{2}\right)$ の成膜を行なった。 $\mathrm{N}_{2} \mathrm{O}$ は先に述べた石英 ガラスの放電管の上部より導入しプラズマを通して堆積 室に入れた. $\mathrm{SiH}_{4}$ と $\mathrm{Ar}$ の混合ガスは堆積室にあるリン グ状の吹き出しロから基板上に導入した。

* 昭和62年11月13日 第28回真空に関する連合講演会で講演 $(13 \mathrm{p}-21)$

** 日電アネルバ株式会社（東京都府中市四谷5-8-1）
本実験では基板上のプラズマの拡散を防ぐために放電 管室と堆積室の間にメッシュを設置した。この状態で成 膜に関する温度依存特性などを測定した。 またメッシュ を取り除いて基板上にプラズマが存在する場合について も測定し，基板上にプラズマが存在していない場合と比 較した．更に高温非平衡プラズマから放射する光の効果 を調べるために放電管と基板との間に遮蔽板を設置した 場合について同様の実験を行った.

\section{3. 実験結果と考察}

\section{1 電力依存特性}

メッシュを用いて堆積室内にプラズマが存在しない場 合に拈いて $\mathrm{SiH}_{4}$ 流量を $3 \mathrm{sccm}, \mathrm{N}_{2} \mathrm{O}$ 流量を $120 \mathrm{sccm}$,

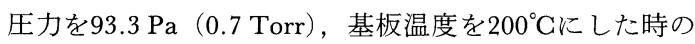
印加電力と成膜速度, 屈折率および酸素原子からの発光 強度の関係を Fig. 2 に示す. 印加電力の強度により放 電管内のプラズマ状態が変化する. 印加電力が約 0.5 $\mathrm{kW}$ 以下の場合ではグロー状放電プラズマであり， 0.5 $\mathrm{kW}$ を越えると高温非平衡プラズマになる，同図におい てグロー状放電プラズマでは $\mathrm{SiO}_{2}$ 膜はほとんど成膜さ れないが, 高温非平衡プラズマになると急激に成膜が始 まる. 一方印加電力が $0.5 \mathrm{~kW}$ を越えると可視光領域で 観測される酸素原子からの発光強度も急激に上昇するこ とから酸素原子が高温非平衡プラズマ内に多量に発生し ていることが予想される，そしてこの酸素原子などの酸 素活性種が多量に基板上に供給されることにより $\mathrm{SiO}_{2}$ 膜が成膜されると思われる.

更に $\mathrm{SiH}_{4}$ 流量を増大させることにより Fig. 3 のよう に成膜速度は直線的に増加する。 


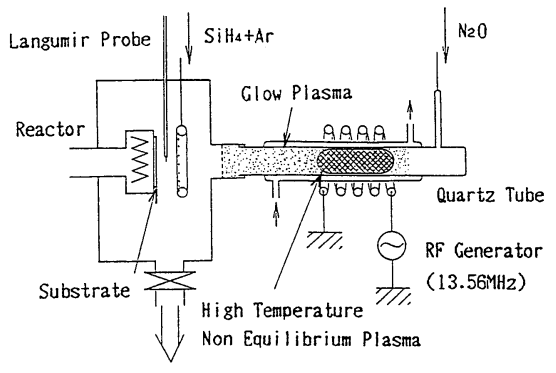

Fig. 1 Experimental system.

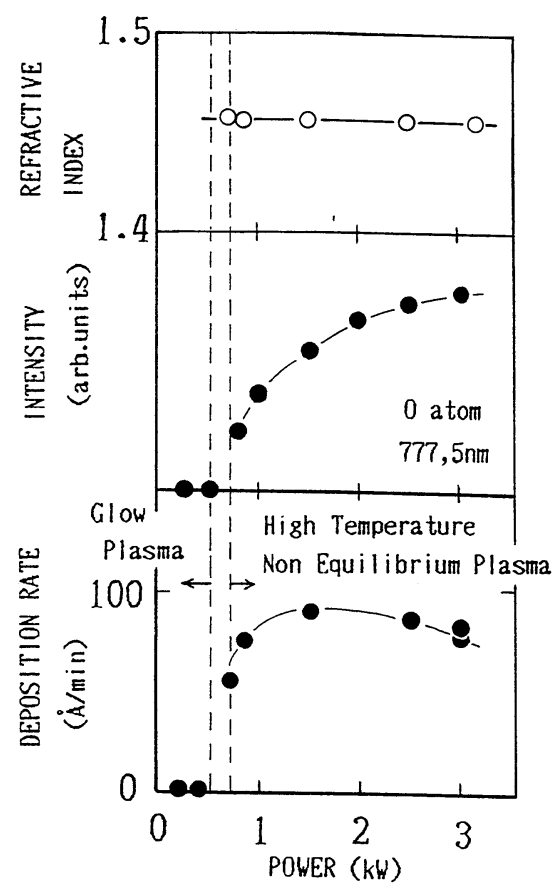

Fig. 2 Deposition rate, refractive index and optical emission intensity of 0 atom versus $R$.F power.

\section{2 温度依存特性}

Fig. 4 に示す三つの状態について成膜時の基板温度依 存特性を測定した。Fig. 4(a) は放電室と堆積室との間 にメッシュがなく，プラズマが基板上に存在する場合で あり，Fig. 4(b) はメッシュを設置することにより基板 表面上にプラズマが存在しない状態を作製した場合であ る. 更に Fig. 4(c) は高温非平衡プラズマから放射され る光を遮断し，活性種のみを通過する構造の遮蔽板をも 設置した場合である．Fig. 5 はこれらの状態について $\mathrm{SiH}_{4}$ 流量を $3 \mathrm{sccm}, \mathrm{N}_{2} \mathrm{O}$ 流量を $120 \mathrm{sccm}$ ，圧力を 93.3 $\mathrm{Pa}$ (0.7 Torr)，印加電力を $3 \mathrm{~kW}$ にした時の基板温度の 逆数と成膜速度の関係を示したものである.プラズマが

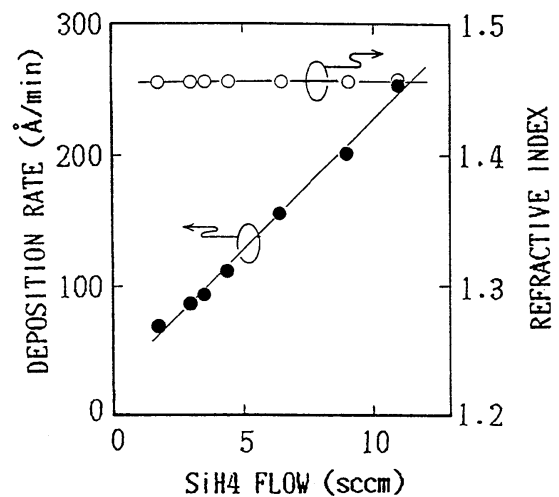

Fig. 3 Deposition rate and refractive index versus flow rate of $\mathrm{SiH}_{4}$ gas.

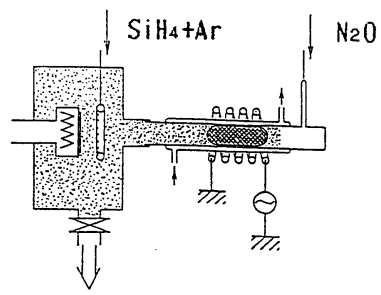

(a) Plasma enhanced deposition

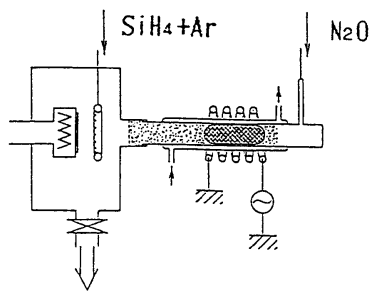

(b) Photo and activated species enhanced deposition

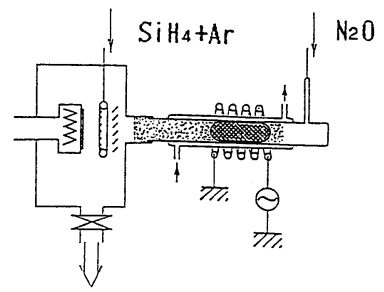

(c) Activated species enhanced deposition

Fig. 4 Deposition methods.

基板上に存在する場合において一直線上に乗らない理由 は反応が複雑に相互作用し基板表面での熱平衡反応が律 速段階となっていないためである。プラズマが存在しな い場合と活性種のみの場合には注淔線上にのってお り，傾きもほぼ同じである。しかし活性種のみの場合に 
$T(K)$

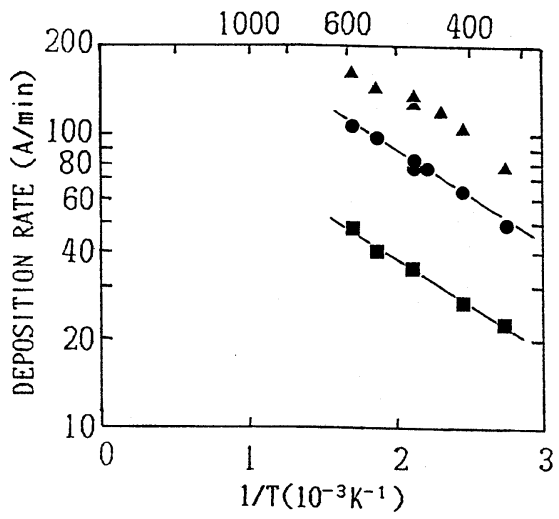

Fig. 5 Temperature dependence of deposition rate.

比べてプラズマが存在しない場合の方が成膜速度は大き い. その原因として高温非平衡プラズマから放射する光 の効果が考えられる. 高温非平衡プラズマから真空紫外 光が強く放射されていることは既して報告している ${ }^{1,2)}$. この真空紫外光によって見掛けの反応断面積が増加し成 膜速度が大きくなったと考えられる．更にアレニウスの 式より見掛けの活性化エネルギーを求めると約 $1.4 \mathrm{kcal} /$ moleであった。 これはTable. $1^{3)}$ のうに $\mathrm{SiH}_{4}+\mathrm{O}_{2}$ 系 および $\mathrm{SiH}_{4}+\mathrm{N}_{2} \mathrm{O}$ 系の 40 または $52 \mathrm{kcal} / \mathrm{mole} に$ 比べて 非常に小さく, 更に活性度の高いオン゙ンを使った $\mathrm{SiH}_{4}$ $+\mathrm{O}_{3}$ 系の $5.2 \mathrm{kcal} / \mathrm{mole}$ よりも若干小さい。この活性化 エネルギーが小さい原因として高温非平衡プラズマによ って多量に発生した酸素原子などの酸素活性種が反応に 関与していると考えられる.

\section{3 プローブ特性}

メッシュによって堆積室内にプラズマが存在しない場 合についてラングミュアプローブ法で電子密度を測定し た。その結果 $10^{7}$ 個 $/ \mathrm{cm}^{3}$ であり, 通常のプラズマ CVD の場合4)より 3 ケタ程度小さい値であった。また。 また プラズマポテンシャルはプラズマ GVDの場合には数百
Table 1 Activation energies of reactant materials

\begin{tabular}{l|c}
\hline \hline Reactant materials & $\begin{array}{c}\text { Activation energy } \\
\text { (kcal/mole })\end{array}$ \\
\hline $\mathrm{SiH}_{4}+\mathrm{H}_{2} \mathrm{O}$ & 64 \\
$\mathrm{SiH}_{4}+\mathrm{O}_{2}$ & 40 \\
$\mathrm{SiH}_{4}+\mathrm{NO}$ & 26 \\
$\mathrm{SiH}_{4}+\mathrm{NO}_{2}$ & 28 \\
$\mathrm{SiH}_{4}+\mathrm{CO}_{2}+\mathrm{H}_{2}$ & 58 \\
$\mathrm{SiH}_{4}+\mathrm{N}_{2} \mathrm{O}$ & 52 \\
$\mathrm{SiH}_{4}+\mathrm{O}_{3}$ & 5.2 \\
\hline
\end{tabular}

$\mathrm{V}$ オーダーである4)のに対して本方式は十数 $\mathrm{V}$ 程度であ った．従って基板への荷電粒子衝突によるダメージは小 さいものと期待される.

\section{4. よ め}

$\mathrm{SiO}_{2}$ 膜を高温非平衡プラズマを用いて作製し，その 膜の温度依存特性などについて測定した.プラズマ源を 基板より遠方に置き，メッシュでプラズマを遮断する方 式においてグロー状放電プラズマでは $\mathrm{SiO}_{2}$ 膜はほとん ぞ成膜されなかったが，高温非平衡プラズマでは急激に 成膜されることがわかった，高温非平衡プラズマを用い た場合反応の活性化ェネルギーは約 $1.4 \mathrm{kcal} / \mathrm{mole}$ と小 さかった．これは高温非平衡プラズマからの酸素活性種 によるものと考えられる。 また高温非平衡プラズマから の真空紫外光は見掛けの反応断面積を増大させる効果が あった。

\section{〔文献〕}

1）第26回真空に関する連合講演会予稿集 $7 \mathrm{Ba}-1$.

2) H. Mito, A. Sekiguchi: J. Vac. Sci. Techol, A-4 (1986) 475 .

3）日本学術振興会薄膜第131委員会編薄膜ハンドブッ ク (1983) p. 199

4) J. L. Vossen: J. Electrochem. Soc. 126 (1979) 319. 